\title{
5 South-North Trajectories and Language Repertoires
}

\author{
Kasper Juffermans \& Bernardino Tavares
}

\section{Introduction}

As a result of relatively affordable technologies of long-distance travel and communication, we live more than ever in an age of mobility and transnational flows (Appadurai 1996). Never before have so many people been able to connect with so many people across such long distances, through physical travel or digital communication. So, twenty-first century migrants are no longer just émigrés and immigrants but typically transmigrants, i.e., mobile persons going back and forth and sustaining multiple engagements and relationships between homelands and new homes. 'The life a person lives as a migrant,' however, Graw and Schielke (2012b, 10) note, 'is often but half of his or her reality, and yet the other half remains often invisible to an outside observer, and often seems also less of a concern for national politics which, in turn, influences the distribution of research funding.' Whereas Vertovec (2010) may be right or wrong in stating that 'more people are now moving from more places, through more places, to more places' (Czaika and de Haas 2014 argue against this), people are now evidently in a state of 'involuntary immobility', i.e., aspiring to migrate but practically incapable to do so (Carling 2002).

Flows of people, texts, and meanings across the globe and globalization and mobility have emerged as major themes in the study of language in society. Work on language and globalization generally points at the relativity of functions, meanings, and uses of language in the increasingly mobile, shifting, and intercultural contexts of daily interaction and encounters. It emphasizes change and fluidity rather than stability and fixity of language and communication, and sees globalization both as a cause of homogenization of language and culture and a source of diversification of linguistic and cultural practices, i.e., as a two-way process that is simultaneously localizing the global and globalizing the local.

But whereas sociolinguistics has recognized power and social class issues in human mobility, from asylum seekers and migrant workers to elite forms of tourism, the new sociolinguistics has perhaps insufficiently engaged with those that are excluded from these flows, with those that don't travel well 


\section{Kasper Juffermans and Bernardino Tavares}

but remain invisible in global ethnoscapes and transcultural flows. Sociolinguistics arguably struggles with the 'not-there', the 'absent presences', with that which and those that are 'left out' (Kulick 2005). Resonating with arguments in the anthropology of mobility (Carling 2002; Graw and Schielke 2012a), this chapter introduces a notion of desire or aspiration in studying language and migration. Between migrant and non-migrant identities, there are migrant identifications and imaginations which are articulated in local language practices and interactions.

This chapter outlines two conceptual tools that are useful in a sociolinguistics of globalization that considers mobility within a context of growing mobile inequalities-trajectories and repertoires-and illustrates their potential on the basis of data from an ongoing project on language and migration between Lusophone West Africa and Europe.

\section{Repertoires}

Repertoire belongs to the classic toolkit of sociolinguistics. Formulated in its most general terms, a repertoire is the totality of linguistic-semiotic resources available in a given space to individuals or a community in local communicative practices. Rymes (2014) explains that repertoire was initially a radical concept in linguistics meant to challenge purist orthodoxies and destabilize linguistic definitions of language as self-evident, sui generis entities. Gumperz (1964) coined the term at a time when scholars of language developed an interest in the social life of language and began to conduct fieldwork in addition to philological methods. It is important to note that fieldwork-in India and Norway for Gumperz-is at the root of the development of sociolinguistics as a discipline. Repertoires describe the range of languages circulating in a community that people strategically draw upon in their transactions on the market place, involving not necessarily full competence in each of the individual languages, but also minimal forms of competence.

Rymes explains that Gumperz' work remained by and large concerned with language: 'he never expanded that concept to include other features of interaction that are beyond language' (7). Gumperz' notion of repertoire was also concerned with the 'speech community' as a whole or with individuals as members of that community. Under globalization communities are becoming more and more complex and diverse, up to the point where the usefulness of a notion as community itself, like language, is being questioned and rethought. Community is commonly conceptualized now either as a myth or historical invention, i.e., as 'imagined communities' (Anderson [1983] 1991) or as more or less flexible, transient networks of members engaged in shared activities, i.e., as 'communities of practice' revolving around doing rather than being (Lave and Wenger 1991).

Han (2013), for instance, draws on the notion of repertoire in her study of African migrant traders' communication and language choices in Guangzhou (China). For her, language repertoire also includes literacy practices 
and emergent forms of multilingualism. Drawing on Blommaert's (2008) Grassroots Literacy, she proposes the term grassroots multilingualism to show how individuals develop their linguistic repertoire locally without formal instruction. For Han, a linguistic repertoire is 'the totality of the different degrees of knowledge and functionality of all of the linguistic varieties learned in a person's life trajectories' (86). Borrowing Bourdieu's notion of capital, she stresses that people's life trajectories are shaped by the accumulation of material and symbolic (including linguistic) capital. For instance, a (Francophone) Guinean storeowner in Africa Town in Guangzhou selfreported that he could speak a little English and had learned a little Chinese from friends in Guangzhou but could use colloquial Mandarin quite effectively in his business transactions.

Independently of each other, Busch (2012) and Blommaert and Backus (2013) have recently revisited the concept of repertoire, situating it not primarily within communities, as Gumperz did, but within individuals. One's repertoire reflects the spaces and networks one navigates and bears the traces of one's biography. Repertoires are dynamic and constantly changing: As one proceeds through life and encounters new individuals or participates in new networks and institutions, one is socialized into new registers, styles, genres and varieties which supplant and supplement previously acquired ones (Blommaert and Backus 2013). A difference in Busch' treatment of repertoire from that of Blommaert and Backus is that for Busch, desire or future potential is as important in the formation of multilingual subjectivities as the traces of one's individual or collective past: 'a linguistic repertoire may not only include what one has but also what one does not have, what one was refused but is still present as desire' (509).

Language desire is developed in more detail by Takahashi (2013) as an alternative for the more simplistic notion of motivation in second language learning. Other than motivation, desire is 'socially and historically constructed at the intersection between individual practices and macro-discourses' (153), thus located not only within but also around the individual learner. Takahashi's study explores the language learning efforts and frustrations of Japanese women studying in Australia, in terms of their desire for creating a new lifestyle and transforming their identities. Their desire is seen against the background of a more general Japanese desire (akogare) for English and Western countries as well as for personal (romantic) relationships with Western men. Repertoires (whether of language, identity, etc.) are therefore as much indexes of people's past as of their present and future actions and identifications. The notion of trajectory is meant to capture the changes over time in one's repertoire as movement between past, present, and future. This brings us to our second conceptual tool.

\section{Trajectories}

The notion of trajectory is a recurrent theme across the humanities and social sciences from applied linguistics, migration studies, and anthropology 


\section{Kasper Juffermans and Bernardino Tavares}

to education and occurs in collocation with themes as diverse as 'life', 'text', 'learning', 'migration', 'family', 'work', 'career', 'home ownership', 'population', 'integration' and 'policy'. The notion is, however, often only little theorized and taken as a common sense metaphor for movement across time and space.

In its most general sense, a trajectory can be defined as 'the path that a moving object follows through space as a function of time' (Wikipedia entry: trajectory, Dec 2014-Jun 2016). Such a moving object may be an apple falling from a tree, a planet moving in an orbit around its sun, or a human being commuting to work. We are concerned here neither with trajectories at the astronomical scale of planets nor at the microscopic scale of daily micro-movements, but with trajectories at the scale of the lifespan. The notion of trajectory is straightforward to imagine, but in this straightforwardness lies a danger of seeing trajectories linearly as movement from A to $B$ (or a sequence of movements between $A$ and $B$ ) without understanding the complexity of relations and the inequalities between A and B (Blommaert, Collins, and Slembrouck 2005). Such lines, of course, are rarely straight lines, and are entangled in complex and often unpredictable ways with other trajectories:

because of the often instantaneous, spontaneous, improvised and random nature of the lines that unfold through individual biographies, and because of the equally unplanned ways in which these individual biographies get caught up and become entangled in other lines and networks of physical and mental contact with other people and other discourses, practices and ideas, the line of one's life is rarely a straight line forward.

(De Boeck 2012, 81)

In medical sociology trajectory has been used in reference to 'a course of illness over time plus the actions taken by patients, families and health professionals to manage or shape the course' (Corbin and Strauss 1992). An illness trajectory consists of various phases or episodes a patient lives through, from diagnosis to recovery or death in the case of terminal illnesses. De Saint-Georges and Filliettaz (2008) applied this notion to learning and interaction in vocational training and defined situated trajectories of learning as the 'temporal organization of collective activities aimed at creating the conditions within which learning can take place' as opposed to the cognitive processes underlying the course of learning, which-like the course of illness-we have little control over (de Saint-Georges and Filliettaz 2008). They emphasize that 'trajectories are . . not fixed in their structure but evolve as part of social and interactional dynamics'.

In a longitudinal study of students transitioning to secondary education in Germany, Budach (2014) critiqued the idealized secondary education trajectories of the late-modern nation-state. Since the beginning of industrialization and the rise of the nation-state, she explains, formal education was 
gradually reconceived from heterogeneous, freely developed trajectories of individual Bildung through voyage, discovery, and experience, to homogenized and rationalized 'straight lines without any detour or aberration and at fast pace' in the service of the labour market. Whereas the former is flexible and unpredictable and can be compared to 'wayfaring' (backpacking is a more contemporary term), the latter can be compared to a package holiday, the modalities of which are pre-set in terms of locale, duration, and activities. Budach shows how consequently language learning is valued very differently in primary and secondary education, from a flexible tool of learning and social inclusion into a rigid target of assessment and social distinction. The notion of trajectory, loosely theorized as a metaphor for how individuals pass through educational institutions and curricular content over time, serves to explain how learning experiences and outcomes are shaped by different cultures and environments of learning, and 'managed' by parents, schoolteachers, and learners themselves. Like Corbin and Strauss (1992) and de Saint-Georges and Filliettaz (2008), she leaves room for a degree of agency distributed across multiple actors and institutions within biological and historical conditions.

For de Costa (2010), learner trajectories are key to understanding the structural and agentive forces that shape adult English second language education. De Costa draws on Bourdieu's concepts of capital, habitus, and field to explain the language and literacy development of one Hmong-speaking Laotian refugee to the U.S. Capital, understood as participants' (and the host society's) investment in language learning in view of increasing the individual's linguistic, cultural, and economic resources, is in itself not sufficient to conceptualize learning. It needs to be 'situated', in Lave and Wenger's (1991) sense, in habitus formation and transformation-i.e., the durable but not eternal skills, dispositions, values, and tastes a learner embodies-as well as in the social field of English language teaching in America. De Costa paints an image of an agentive language learner that is neither free of its own biography and wider ideological and political agendas, nor determined by it.

Migration researchers have argued for a trajectory perspective of migration, i.e., for seeing migration as a dynamic process unfolding over time. This process is managed by immigration and emigration regimes as well as individual agentive strategies in response to changing regimes. Ho (2011), for instance, describes the experiences of Singaporean highly-skilled transnationals in London in terms of 'accidental navigators' and 'self-initiated global careerists' and emphasizes the dynamics of migrant strategies, subjectivities, and categories over time. Their migration experience, she points out, is often sliced into episodes with shifts in visa status and social positionings (118). Grillo (2007, 204-5) has criticized postmodernists for merging 'different states of in-between-ness' and for celebrating cultural hybridity while overlooking social class in analyses of transmigration. One of these postmodernists, for Grillo, is Appadurai: 'What Appadurai says is sometimes 


\section{Kasper Juffermans and Bernardino Tavares}

astonishingly naïve: 'Everyone has relatives working abroad' (1996, 171). How true! We are all transnationals now, but some more than others, and certainly in different ways.' Carling's (2002) aspiration/capacity framework shares many of these concerns, but complements and complicates the picture with involuntary immobility as a state of being.

A trajectory approach to migration and language attempts to makes sense of the practical and cognitive challenges, structural and agentive forces, and the changing subject positions in individual projects of (trans)migration, after, during, and before migration.

\section{Our Research Context and Participants}

Let us now move to our specific research context. Our project, which is funded by the FNR, Luxembourg, explores sociolinguistic trajectories and repertories of both aspiring and accomplished migrants from a multi-sited perspective both in the South (Cape Verde and Guinea-Bissau) and in the North (Luxembourg). We will here report on our work in the South, focusing on mobilities in the making and on migrants before they become visible as migrants from the viewpoint of the states in the North to which they aspire to travel.

The two countries of fieldwork, both in Atlantic West Africa, are intimately linked historically. Colonized by Portugal, Guinea-Bissau and Cape Verde gained their Independence in 1974 and 1975 through a long joint struggle led by the PAIGC (Partido Africano da Independência de GuinéBissau e Cabo Verde). The party's founder and leader until his assassination in 1973, Amilcar Cabral, was of mixed Cape Verdean and Bissau-Guinean descent and is still regarded as the father of both nations. Both countries are presently member states of the Community of Portuguese Language Countries and have many cultural and linguistic commonalities, including a mutual migrant presence, and largely mutually intelligible national languages (Cape Verdean and Guinean Creole). Their political and economic situations, however, are quite distinct. Since Independence, Cape Verde has been relatively stable and peaceful, whereas Guinea-Bissau has known successive coups d'état, military governments, and a civil war (1998-99). This reflects on their contrastive economic situations, with Cape Verde representing one of the more prosperous West African states and Guinea-Bissau being identified among the world's least developed countries (cf. Human Development Index) and as a fragile or failing state (Bybee 2011).

We've conducted parallel fieldwork-Bernardino in Cape Verde and Kasper in Guinea-Bissau-for about six months between January 2014 and March 2016. Bernardino is a native of Cape Verde but had been living outside of Cape Verde (mainly in Portugal) for seven years prior to the start of the project, when he moved to Luxembourg with his family. He is from Santiago Island but his fieldwork concentrates on the islands of Santo Antão and São Vicente (Mindelo). Kasper grew up in the Netherlands and Belgium 
and has been a regular visitor to West Africa (especially The Gambia, see Juffermans 2015) since 2001, but began learning Creole only at the start of this project.

Our fieldwork consisted of observations of and conversations about (foreign) language learning in function of migration, mobility, and travellingwhich in Creole is denoted by the same word, 'bias/viaji'. After initial contacts and friendships were established, we interviewed (and re-interviewed) several dozen young Luso-Africans about their language life and mobile experiences or aspirations. Participants were approached in meeting places for foreign language learners (e.g., language schools) or were suggested on referral through other participants. All interviews were open-ended and only minimally structured and lasted from 15 minutes to over an hour. Bernardino interviewed in Cape Verdean Creole (with occasional insertions of Portuguese and French) and Kasper in English and French (with occasional insertions in Guinean Creole and Mandinka).

Our study takes a narrative approach in analyzing the interview data. The participants' responses are taken as autobiographic accounts (Pavlenko 2007) and are analyzed not as chronological histories but as narrations of multilingual and mobile/immobile selves. Key events and anecdotes are taken to reconstruct their language lives, their mobile experiences and/or desires, and the social worlds in which they are situated. In what follows we explore the language lives and learning histories, (unfinished) travels and further mobile aspirations, and changing social status of three young Luso-Africans.

\section{Three Young Luso-Africans on the Move}

Herina (her real name) is in her early twenties and is a housemaid in Mindelo on the island of São Vicente in Cape Verde. In addition to Cape Verdean Creole and Portuguese, she speaks a little French and English. Her closest relatives (parents, brothers, and sisters) are all in Italy. Despite her family's strong transnationalism, she herself epitomizes the figure of the involuntary immobile. She has a long track-record of failures in trying to travel to Europe. She has applied for visas seven times (to the Netherlands, Italy, and France), but she got all of them refused. When asked about the reasons the embassies and consulates gave her for their refusals, she said: 'nau nunka es dize nada, sinplismenti es da kes papel, es ta rikuza vist mas nada' [no, they never say anything, they simply give the papers back, they deny visa and nothing else].

She has spent a lot of money applying for visas and she is still saving from her low-paid job as well as counting on her family in order to prepare and apply again. She is resilient and determined to move to Italy or anywhere else in Europe. She pointed out: ' $N$ ta prefiri ba pa Italia, tud manera tud jenti ta la' [I prefer to go to Italy, anyway all my relatives are there]. Family reunion is her migration goal, but since she is adult now it is difficult to get a 


\section{Kasper Juffermans and Bernardino Tavares}

visa through this mode. Furthermore, her job category (as a housemaid) and her young age position her as a potential over-stayer for the immigration officials. Her experience suggests that failing in getting a visa once makes it even more difficult for the next time and that rejections can turn into a spiral process.

Herina is not naïve about migrant life, and is very aware of the hardship and difficulties many migrants face in this world. But that awareness does not make migration any less desirable for her; in contrary, it makes her mobile aspirations a matter of dignity and a moral endeavour. She pointed out:

txeu jenti ta dize ki emigrason e iluzon purk la bu ta dize ki bu ta ten un vida midjor em termos economico, mas si nu ben spial el ne asin. Purk asves immigrant ta pasa mas difikuldad du ki nos ki ten stadu li . . . as vezis bu podi trabadja y es ka rikonpensob manera ki es divia many people say that emigration is an illusion because there you say that you will have a better life in economic terms, but if we come to see it, it is not like that. Because sometimes immigrants face more difficulties than us who have been staying here ... sometimes you can work and they do not compensate you as they should

She is what Akesson (2008) termed 'a transnational at home'. She is very informed about life in Europe by friends and relatives abroad. Their stories and experiences are important push and pulls of her mobility. However, she is very aware about the harsh realities of immigrant life in Europe. She pointed out that going to Europe is not about fun but hard work, 'Europa bu ta bai mas e pa ba trabadja, pasa sabi pasa sabi bu ta pasa sabi na bo tera' [one goes to Europe mostly for working, having fun you have it in your country].

Herina's case shows that a strong family network abroad is in itself not enough to accomplish migration. The case also shows that decisions about migration or non-migration taken by European consular services are far from transparent for applicants such as Herina. For Herina, acquiring the rights to travel is a long and cumbersome journey with many disappointments along the road. Globalization manifests itself to Herina, and many others like her, mostly in terms of its absence or elusiveness (cf. Graw 2012): Europe is extremely visible and present in Herina's life, but Herina herself, with her ambitions and skills set, remains invisible and absent in the North. Schengen's migration regime successfully keeps her out of Europe, in place, denying her access to her family and the European labour market. Her reasons and motivations to travel are simply 'disqualified by law'; the regime considers her-seven times in a row-ineligible, i.e., 'unfit' or 'unworthy of being chosen' (Gaibazzi 2013, 39), and so she remains involuntary and invisibly immobile.

Kode (a pseudonym) from Guinea-Bissau was a student of political science and international relations in his early twenties before the polytechnic 
institute he studied at collapsed. He is an active member of the English Club at the American Corner of Bissau and he is very determined to move out of Guinea-Bissau. His trajectory of multilingualism shows passion for foreign languages and a relative indifference to local languages:

You know we have a local language, which is Creole. It is the first language I start learning. I learn it from my parent at home, although we don't learn it at school. We have our first language, which is Portuguese, our official language. [. . .] I speak a little bit of Mandjago of course. Mandjago. That's my ethnic group. But I don't speak it that well. I went to the village just once, for six months. After that I never lived there again. Because in my house nobody speaks it.

Kode decided to study foreign languages and chose English, 'as the first language of the world.' He joined a private language school while in sixth grade and made a quick career in learning English and began teaching it at the age of 15, long before he finished his secondary education. Subsequently, Kode taught himself Spanish through an online course and from taking classes with a Cuban man working in Guinea-Bissau, and claims now to speak Spanish 'just like the way I speak Portuguese'. When Kasper first met him in 2014, he was studying a fourth European language, French. Prompted about this, he explicitly connected his foreign language desire with his aspirations for transnational mobility:

Yes, I decided to join the French community because I know that, all I'm thinking is to go out of out of this country. [. . .] to look for immigration, or to go for study. I know that French is gonna be a tool I will need. If I don't do it here, any day I will need it, I will regret why I didn't do it.

The rest of the two interviews and Kasper's casual conversations with him focused on his efforts and investments in seeking mobility. His desire to leave Guinea-Bissau, he emphasized, needs to be understood against the background of the weak state and lack of educational and professional opportunities for young people in Guinea-Bissau. For Kode, like many young men (and women) in Guinea-Bissau (cf. Bordonaro 2009), going out is an obsession, a necessity for personal development and social upward mobility, as well as a patriotic moral obligation: 'I am doing ever- at all cost to get out of this country, to give better contribution to my country'. Kode's efforts, however, have only resulted in disappointments so far. Three of these disappointments and his understanding of why his efforts failed are given below:

(1) 'When I was a kid, [my aunt] always promised my mum she was going to take me to England, once I finished my high school'. His aunt's promise was a motivation for Kode to excel in school and focus on English. He did 


\section{Kasper Juffermans and Bernardino Tavares}

his part, and counted on his aunt to do her part. 'I told her now I speak English'.

The problem is she has to adopt me as her son. She sent me 200,000 [CFA—about $€ 300]$. We make the passport. After, we send documentation to England. We send it to Dakar and they send it to England. After two weeks they say the names came out, but my name didn't come out. [. . .] But what I realize, she didn't have enough money for the three of us. So she decided to help only her sons and not me.

(2) A friend working at the American diplomatic office in Bissau tells Kode about the 'Young African Leaders Initiative', a prestigious program for 'executive leadership training, networking, and skills building' set up by President Obama in the U.S. 'to invest in the future of Africa' (YALI website). His friend said: 'There is opportunity for you to go'. Kode investigated the requirements thoroughly; he corresponded with a Kenyan YALI alumnus he found on the internet; he met with American Embassy staff visiting the American Corner in Bissau and made a good impression with them. $\mathrm{He}$ also generously helped others with the application procedure. In addition, he spend 200,000 CFA changing his birth date to meet the program's minimum age requirement of 25 . This requires buying a new birth certificate, passport, and school certificates. He is one of three persons shortlisted for an interview, but finally two non-shortlisted candidates are selected. For Kode it is clear that 'corruption' is in play. 'The ambassador was very mad about the situation. They select people that did not meet the criteria. [. . .] They couldn't even speak English. [ . . ] Before it made me mad, but I said, let me just wait'.

(3) Together with two friends (male and female), Kode applies for a threemonth scholarship to India at their consulate in Bissau: 'We did it and we deliver at the same day. After one, two weeks, they called the girl to go. They asked her about the rest of the documentation. But they never called us. That man I know him like the back of my head. His business is for money or girls. He likes small girls. He is very serious by face, but he's a very dangerous guy'.

Corruption emerged as a major theme in the conversations with Kode. Travelling to the UK to meet his aunt required him to get the papers in which his aunt appeared as his mother; the YALI scheme required him to change his birth date. The corruptions Kode engaged in are, other than what he witnessed at the Indian consulate, victimless 'crimes'. He did it only to find his way, as a means of responding to scarce opportunities:

What I did before is also a corruption. It's just like a crime. [. . .] But why I'm doing it, not to kill somebody, I'm doing it only to find my way. [...] I did it because I know this is not a country of opportunity. I found this opportunity, that's why I say okay let me take opportunity since 
there is opportunity for me to go, let me do it at all costs, okay exception killing or hurt somebody. And that's why I changed it. Because I know that, maybe there will not be such opportunity like this.

Kode manouevres, or 'navigates' in Vigh's $(2006,54)$ terms, 'through unstable social terrains', making agentive and creative use of local bureaucracies in order to satisfy the demanding documentary requirements imposed on him.

Kode's case has much in common with that of Herina: It shows that transnational family ties often fail as strategies to travel, that institutional decisions about mobility are obscure and often (perceived to be) unfair. Like Herina, Kode's case also testifies to the immense perseverance and stamina involved in seeking mobile life trajectories. Globalization manifests itself to Kode also in terms of absence but Kode's strategies are more diversified than Herina's, and he also seems to believe more than Herina that he is getting reasonably closer to accomplishing mobility with each attempt. With each attempt, Kode's knowledge and skills about travelling, his mobility repertoire so to speak, grows. As he prepares himself academically for travel opportunities and through language learning in particular, he positions himself better in his own society, which in turn enhances his mobility potential.

Eunice (real name) from Cape Verde is in her mid-thirties and a receptionist at the Cape Verde Multilingual School in Praia. The school offers English, French, German, Spanish, Italian, Arabic, Russian and Chinese language classes for local children and adults and Portuguese and Creole classes for (mainly) foreigners. Besides Cape Verdean Creole and Portuguese, Eunice speaks French and little English, which she learned as part of her high school curriculum.

Her foreign language learning in school was, contrary to Kode, not very passionate but rather obligational. She said she was not very conscious about the value of foreign languages until she began to travel. In high school she developed affection for France in her French classes, but this was more about the Eiffel Tower, the Champs-Élysées, and the map of France than about the French language.

Unlike the previous two participants, Eunice is relatively mobile as she has had the chance to travel to Portugal, France, and the U.S.. She worked as a selling operator at the national telecommunications operator CVMovel for about three years, selling products to local and foreign customers. When she encountered communication problems with tourists or foreign business people, she would pass the telephone to an engineer whose English and French were better than hers. At night, however, she resorted to Google Translate struggling to make herself understood.

While working for this company, she applied for tourist visas to Portugal. The first one she got was in 2007 to visit her grandmother. She kept renewing her one-year Schengen visa every year, and in 2010 she used it to visit her aunt in France. Once in France she was diagnosed with some health problems, and was advised to take appointments with Medicins $d u$ 


\section{Kasper Juffermans and Bernardino Tavares}

Monde which made her postpone her travel back to Cape Verde for almost one year, but she managed to return before her visa expired. Her travel to France motivated her to invest more in learning French, so that when she returned to Cape Verde she took a course at the Institut française. At the time Bernardino met her in 2014 and 2015 she regularly watched the news on TV5 Monde, listened to French songs, and had French friends living in or regularly visiting Cape Verde.

When asked about the benefits of her travel to France, she answered that besides solving her health problems, 'foi ih aprendi, foi prendi lida ku pesoas di kulturas diferenti, linguas diferenti' [it was learning to cope with people from different culture, different language], which in turn could be professionally advantageous. She added that she aspires to work for the French or Luxembourgish cooperation agencies in Cape Verde and so French is one of the most important tools to achieve that goal. During her stay in France, some incidents made her even more aware of the importance of learning French. For instance at Charles-de-Gaulle Airport she got embarrassed because she had not specified to her aunt at which terminal she would arrive:

$\begin{array}{ll}\text { Kantu N bai pa kel uma aeroportu } & \text { When I went to that big airport, I said } \\ \text { grandi N fla Ave Maria, nton N odja } & \text { Ave Maria, so I saw the man who gives } \\ \text { kel sinhor ki ta da informason. N bai } & \text { information, I went and I said sir, I said } \\ \text { N fla sinhor N fla si: bonjour monsieur, } & \text { so: bonjour monsieur, and he said: } \\ \text { e fla si: bonjour madame, N fla si: } & \text { bonjour madame, I said so: [in French] } \\ \text { monsieur je suis perdue comment est-ce } & \text { 'sir, I'm lost, what can I do to call my } \\ \text { que je peux faire pour appeler ma mere } & \text { mother [aunt]?' and he said 'do you } \\ \text { [tante]? e fla si: vous avez le numéro? } & \text { have the number?' I said 'yes', so he } \\ \text { N fla: oui, nton e fla: donnez-moi } & \text { said: 'give it to me please.' So I gave } \\ \text { s'il vous plait. Nnton N dal numeru, } & \text { him the number and he called my aunt } \\ \text { e txoma nha tia y nha tia bai na mi. } & \text { and my aunt came to me. But if I had } \\ \text { Mas si pur akazu N ka tinha nuson di } & \text { not had any notion of the language } \\ \text { lingua ja [. . .] si N ka sta konsentradu } & \text { [.. .] if I was not concentrated I would } \\ \text { N ta fikaba prekupadu, ku prekupason, } & \text { be more worried, with worry, because } \\ \text { pamodi e un pais ki nunka N baba. } & \text { it was a country I had never been to } \\ \text { Nton senpri N ta fla ma lingua e } & \text { before. So I always say that language is } \\ \text { inportanti. } & \text { important. }\end{array}$

After her first travel to Portugal but before her visit to France, she applied for a visa to the USA U.S. in 2008. She filled the application form on the internet portal of the U.S. Embassy in Cape Verde and later went personally to the embassy with her salary statement. She was granted a B2 visa valid for five years, allowing her one or more visits of up to six months. She only used it in 2013 just before it expired. Similarly to her incident at the airport in Paris, at the airport she had some embarrassment when a border police asked her whom she was going to visit. She didn't know how to say madrinha [godmother] in English. Reflecting on that, she said that now before travelling, she will prepare a list of vocabulary that she may need the most during her stay abroad. Acquiring a visa to the US is relatively 
accessible to Cape Verdean professionals with a well-paid position, and professionals like Eunice commonly apply for it even without concrete travel plans. Having an American visa sticker in one's passport is believed to be an asset for acquiring visas to other countries, too.

Eunice's case shows that mobility does not always (often not) emerge as a result of language learning, but that travelling on the other hand may lead to a greater awareness of and need for foreign languages. At the same time, Eunice's expanding repertoire (she became fluent in French) made her aspire to travel and get to know the world even more. Unlike Kode, her language repertoire follows rather than anticipates her movements. Eunice's trajectory suggests that getting a visa once makes it easier to get another one. In this respect, travelling is like money: The more one has of it, the easier it becomes to acquire even more of it.

\section{Discussion and Conclusion}

By means of conclusion, the map below visually summarizes the failed attempts and successful South-North travels discussed above. The map is relatively global in scale, because so are the (attempted) travels of Herina, Kode, and Eunice. A smaller-scaled map in which the geographies of Cape Verde and Guinea-Bissau would be more visible, would make the projected destinations disappear from the map. Making their (aspired) northward, westward, and eastward movements visible reduces the visibility of their countries of origin to mere dots on this global map.

Herina, Kode, and Eunice are three young Luso-Africans located in their countries of origin, differently positioned vis-à-vis their mobility. Unlike Eunice, Herina and Kode are not (yet) transnationally mobile but rather 'transnationals at home' (Åkesson 2008). Herina's mobile desire and strategies to find transnational mobility are mainly based on her family network with individuals already living in Italy. Her relatively low social-economic status in Cape Verde, as a housemaid, and her limited education severely restricts her chances at finding mobility. Repeatedly, her applications for visas are denied by the authorities. Kode in Guinea-Bissau has relatives in the UK (and elsewhere), but he mainly seeks educational opportunities to travel. Opaque and unfair selection procedures prevented him from travelling to the U.S. and India. These series of disappointments do not make Kode to give up, but rather to try harder, to invest more in his multilingual repertoire by learning French as a fourth European language. Herina, however, is getting tired of the constant rejections. While we prepared this chapter for publication, she informed Bernardino of an eighth rejection (to Portugal this time), and wrote ' $j a$ N ti ta perde speransa' [I am losing hope already] and that she's been thinking of travelling 'di verso' i.e., through bribing or in the clandestine way.

We've contrasted these two cases of involuntary immobility with that of Eunice, who is older and through her work better positioned to find 


\section{Kasper Juffermans and Bernardino Tavares}

mobility. Her successful travels to France and beyond illustrate the violence that's done by Europe's restrictive immigration policies on Herina and Kode, i.e., excluding them from an experience and denying them progress in their personal and educational development. Contrasting Kode's with Eunice's case also illustrates the limits of acquisition of linguistic capital for migration. Language learning helps, but is by no means enough (for Kode) and often (for Eunice) not even necessary to find mobility. A cynical conclusion to draw here is that corruption works better.

The notion of desire in relation to repertoires and trajectories is necessary in understanding language in/and mobility and allows for a nuanced and complex understanding of agency. While we have little choice over what languages we are socialized in, or the places we are born in, we can, to some extent, take actions to influence or manage our linguistic repertoire as well as the places to which we move. It is clear from the above cases that few of these decisions are solely individual and that migration requires serious investment. It is also clear that all of these 'choices' depend on prior choices and opportunities and broader material, cognitive, and socio-political conditions. Understood in this way, trajectories follow the 'arrow of time' (Prigogine 1997), i.e., the past is irreversible and affects although not completely determines the future course of the trajectory.

The three cases presented here have shown that South and North are intimately connected. Even if these connections are not always experienced as physical interactions and movements back and forth, they are very real and intense in the form of imagination, desire, or aspiration. For each solid line on a map like that of Figure 5.1, there are many more dashed lines of unfulfilled itineraries. This work of imagination, the personal investments in northward mobility and their disappointments in the South remain largely

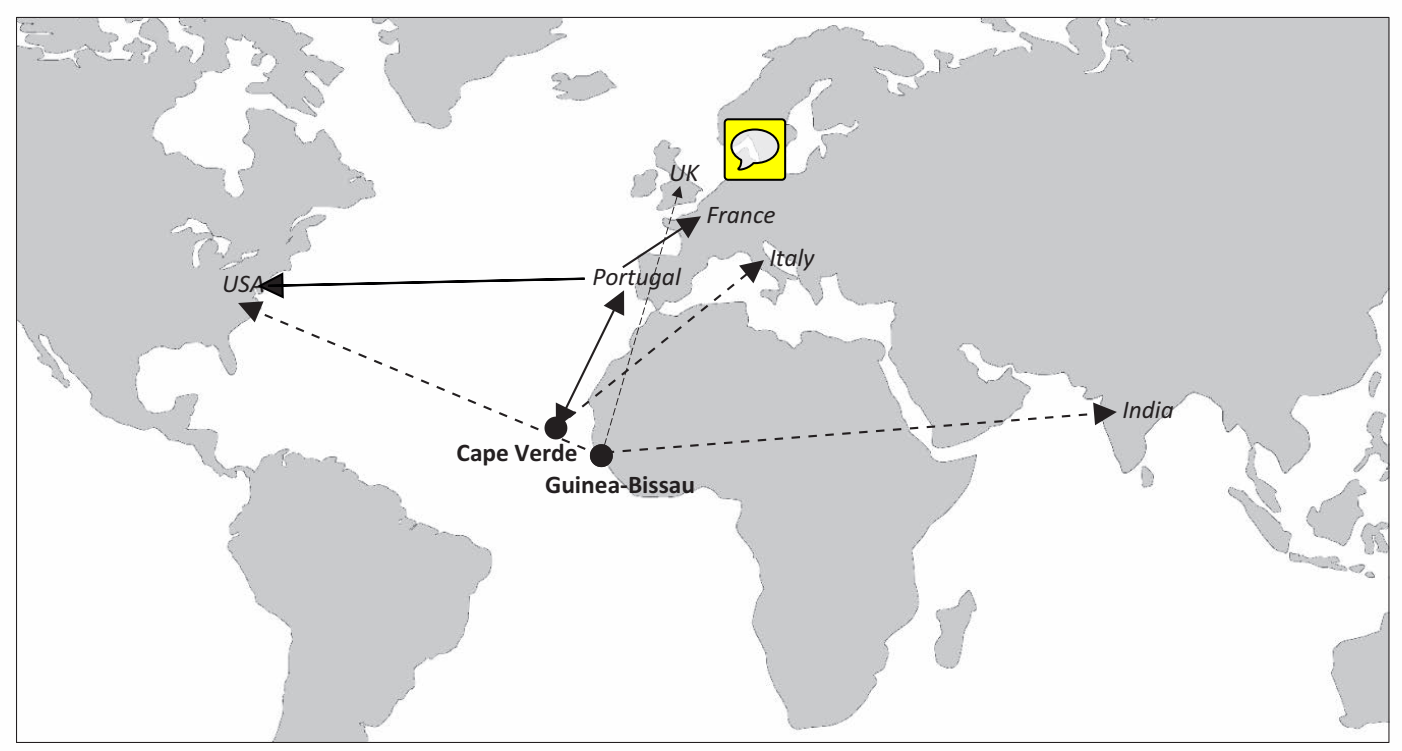

Figure 5.1 Failed and Effective South-North Trajectories 
invisible and are disenchantingly absent from debates about migration in the North. What these debates and policies seem to be unable or unwilling to grasp is that the southern object of desire is not migration to the North as a linear and one-off path from $\mathrm{A}$ to $\mathrm{B}$, but travelling in the form of realizing interaction between $\mathrm{A}$ and $\mathrm{B}$ for personal, family, and national development. The ever more restrictive migration regimes in the North may intend to control and curb migration, but in doing so oppress all forms of travel, which cynically encourage illegal and often tragic passages over sea as well as perverse forms of corruption and fraud. Beginning to understand SouthNorth travel also in terms of adventure and journeying (Sarró 2009) and as attempts to escape immobility and global inequality and seek personal and national development, is sorely needed to disentangle discourses of SouthNorth mobilities. Acknowledging the deep and sharp mobile inequalities between cosmopolitan citizens (mobile haves) and involuntary immobile subjects (mobile have-nots) in today's globalizing world, and understanding mobility as another 'site of struggle' (recall Stroud's 2001 discussion of linguistic citizenship) could help in transforming current South-North injustices.

\section{References}

Åkesson, L. 2008. 'The Resilience of the Cape Verdean Migration Tradition'. In Transnational Archipelago: Perspectives on Cape Verdean Migration and Diaspora, edited by L. Batalha and J. Carling, 269-83. Amsterdam: Amsterdam University Press.

Anderson, B. [1983] 1991. Imagined Communities: Reflections on the Origin and Spread of Nationalism, Second Edition. London: Verso.

Appadurai, A. 1996. Modernity at Large: Cultural Dimensions of Globalisation. Minneapolis: University of Minnesota Press.

Blommaert, J. 2008. Grassroots Literacy: Writing, Identity and Voice in Central Africa. London: Routledge.

Blommaert, J., and A. Backus. 2013. 'Superdiverse Repertoires and the Individual'. In Multilingualism and Multimodality: Current Challenges for Educational Studies, edited by I. de Saint-Georges and J.-J. Weber, 11-32. Rotterdam: Sense.

Blommaert, J., J. Collins, and S. Slembrouck. 2005. 'Spaces of Multilingualism'. Language \& Communication 25 (3): 197-216.

Bordonaro, L. I. 2009. 'Sai fora: Youth, Disconnectedness and Aspiration to Mobility in the Bijagó Islands (Guinea-Bissau)'. Etnográfica 13 (1): 125-44.

Budach, G. 2014. 'Educational Trajectories at the Crossroads: The Making and Unmaking of Multilingual Communities of Learners'. Multilingua 33 (5-6): $525-49$.

Busch, B. 2012. 'The Linguistic Repertoire Revisited'. Applied Linguistics 33 (5): 503-23.

Bybee, A. N. 2011. Narco State or Failed State? Narcotics and Politics in GuineaBissau. Fairfax, VA: School of Public Policy, George Mason University.

Carling, J. 2002. 'Migration in the Age of Involuntary Immobility: Theoretical Reflections and Cape Verdian Experiences'. Journal of Ethnic and Migration Studies 28 (1): 5-42. 


\section{Kasper Juffermans and Bernardino Tavares}

Corbin, J. M., and A. Strauss. 1992. 'A Nursing Model for Chronic Illness Management Based upon the Trajectory Framework'. Research and Theory for Nursing Practice 5 (3): 155-74.

Czaika, M., and H. de Haas. 2014. 'The Globalization of Migration: Has the World Become More Migratory?’ Internaional Migration Review 48 (2): 283-323.

De Boeck, F. 2012. 'City on the Move: How Urban Dwellers in Central Africa Manage the Siren's Call of Migration'. In The Global Horizon: Expectations of Migration in African and the Middle East, edited by K. Graw and S. Schielke, 59-86. Leuven: Leuven University Press.

de Costa, P. 2010. 'From Refugee to Transformer: A Bourdieusian Take on a Hmong Learner's Trajectory'. TESOL Quarterly 44 (3): 517-41.

de Saint-Georges, I., and L. Filliettaz. 2008. 'Situated Trajectories of Learning in Vocational Training Interactions'. European Journal of Psychology of Education 23 (2): 213-33.

Gaibazzi, P. 2013. 'Visa Problem: Certification, Kinship and the Production of "Ineligibility" in the Gambia'. Journal of Royal Anthropological Institute 20: 38-55.

Graw, K. 2012. 'On the Cause of Migration: Being and Nothingness in the AfricanEuropean Border Zone'. In The Global Horizon: Expectations of Migration in African and the Middle East, edited by K. Graw and S. Schielke, 23-42. Leuven: Leuven University Press.

Graw, K., and S. Schielke. 2012a. The Global Horizon: Expectations of Migration in African and the Middle East. Leuven: Leuven University Press.

- 2012b. 'Introduction: Reflections on Migratory Expectations in Africa and beyond'. In The Global Horizon: Expectations of Migration in African and the Middle East, edited by K. Graw and S. Schielke, 7-22. Leuven: Leuven University Press.

Grillo, R. 2007. 'Betwixt and Between: Trajectories and Projects of Transmigration'. Journal of Ethnic and Migration Studies 33 (2): 199-217.

Gumperz, J. J. 1964. 'Linguistic and Social Interaction in Two Communities'. American Anthropologist 66 (2, 6): 137-53.

Han, H. 2013. 'Individual Grassroots Multilingualism in Africa Town in Guangzhou: The Role of States in Globalization'. International Multilingual Research Journal 7: 83-97.

Ho, E. L.-E. 2011. 'Migration Trajectories of "Highly Skilled" Middling Transnationals: Singaporean Transmigrants in London'. Population, Space and Place 17: 116-29.

Juffermans, K. 2015. Local Languaging, Literacy and Multilingualism in a West African Society. Bristol, UK: Multilingual Matters.

Kulick, D. 2005. 'The Importance of What Gets Left Out'. Discourse Studies 7 (4): 615-24.

Lave, J., and E. Wenger. 1991. Situated Learning: Legitimate Peripheral Participation. Cambridge: Cambridge University Press.

Pavlenko, A. 2007. 'Autobiographic Narratives as Data in Applied Linguistics'. Applied Linguistics 28 (2):163-88.

Prigogine, I. 1997. The End of Certainty: Time, Chaos, and the New Laws of Nature. New York: Free.

Rymes, B. 2014. Communicating beyond Language: Everyday Encounters with Diversity. London: Routledge. 
Sarró, R. 2009. 'La aventura como categoría cultural: apuntes simmelianos sobre la emigración subsahariana'. Revista de Ciências Humanas 43 (2): 501-21.

Stroud, C. 2001. 'African Mother-Tongue Programmes and the Politics of Language: Linguistic Citizenship versus Linguistic Human Rights'. Journal of Multilingual and Multicultural Development 22 (4): 339-55.

Takahashi, K. 2013. Lang e Learning, Gender and Desire: Japanese Women on the Move. Bristol, UK: Jtilingual Matters.

Vertovec, S. 2010. 'Towards Post-Multiculturalism? Changing Communities, Conditions and Contexts of Diversity'. International Social Science Journal 61 (199): 83-95.

Vigh, H. E. 2006. 'Social Death and Violent Life Changes'. In Navigating Youth, Generating Adulthood: Social Becoming in an African Context, edited by C. Christiansen, M. Utas, and H. E. Vigh, 31-60. Uppsala: Nordic Africa Institute. 
